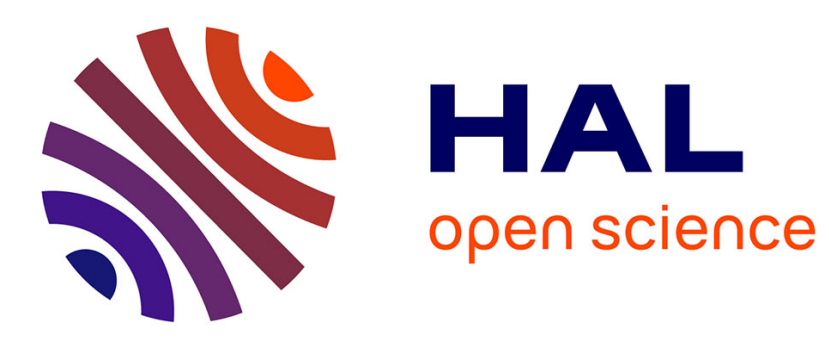

\title{
ASPECTS ISOTOPIQUES DU CYCLE ATMOSPHÉRIQUE DE L'EAU
}

Liliane Merlivat

\section{To cite this version:}

Liliane Merlivat. ASPECTS ISOTOPIQUES DU CYCLE ATMOSPHÉRIQUE DE L'EAU. Journal de Physique Colloques, 1975, 36 (C8), pp.C8-11-C8-11. 10.1051/jphyscol:1975802 . jpa-00216422

\section{HAL Id: jpa-00216422 https://hal.science/jpa-00216422}

Submitted on 1 Jan 1975

HAL is a multi-disciplinary open access archive for the deposit and dissemination of scientific research documents, whether they are published or not. The documents may come from teaching and research institutions in France or abroad, or from public or private research centers.
L'archive ouverte pluridisciplinaire HAL, est destinée au dépôt et à la diffusion de documents scientifiques de niveau recherche, publiés ou non, émanant des établissements d'enseignement et de recherche français ou étrangers, des laboratoires publics ou privés. 


\title{
ASPECTS ISOTOPIQUES DU CYCLE ATMOSPHÉRIQUE DE L'EAU
}

\author{
L. MERLIVAT \\ Département de Recherche et Analyse. \\ Section de la Recherche et de l'Interaction du Rayonnement avec la Matière, C.E.N., \\ Saclay, 91190 Gif-sur-Yvette, France
}

\begin{abstract}
Résumé. - Les isotopes stables de l'hydrogène et de l'oxygène sont à l'état de traces dans les eaux naturelles sous forme de molécules $\mathrm{HDO}$ et $\mathrm{H}_{2}^{18} \mathrm{O}$, les rapports $\mathrm{HDO} / \mathrm{H}_{2}^{16} \mathrm{O}$ et $\mathrm{H}_{2}^{18} \mathrm{O} / \mathrm{H}_{2}^{16} \mathrm{O}$ étant respectivement de l'ordre de $3 \times 10^{-4}$ et $2 \times 10^{-3}$. La volatilité des molécules lourdes HDO et $\mathrm{H}_{2}^{18} \mathrm{O}$ est inférieure à celle de $\mathrm{H}_{2}^{16} \mathrm{O}$ et par conséquence on observe un fractionnement isotopique lors des changements d'état de l'eau, en particulier évaporation et condensation. Dans le cycle de l'eau atmosphérique, chaque étape est marquée par un fractionnement dont la valeur dépend des conditions d'évaporation prévalant à la surface des océans et de condensation lors de la formation des précipitations.

Le tritium, injecté dans la haute atmosphère par les explosions thermonucléaires, constitue un troisième traceur pour l'étude du cycle de l'eau atmosphérique, complémentaire des deux précédents. On met en particulier à profit la localisation dans le temps et dans l'espace de l'injection des molécules HTO dans la stratosphère puis la troposphère.

L'analyse de la répartition du deutérium, de l'oxygène 18 et du tritium dans les eaux naturelles conduit à des applications :

en météorologie : étude de trajectoires de masses d'air, formation de la grêle ;

en hydrologie : origine, temps de renouvellement et de transit d'eau dans un système;

en glaciologie : origine d'échantillons de glace polaire, mesures d'accumulation, études paléoclimatologiques;

en océanographie : identification de masses d'eau, leur mélange.
\end{abstract}

Abstract. - Stable isotopes of hydrogen and oxygen are found in natural waters as HDO and $\mathrm{H}_{2}^{18} \mathrm{O}$ molecules, the ratios $\mathrm{HDO} / \mathrm{H}_{2}^{16} \mathrm{O}$ and $\mathrm{H}_{2}^{18} \mathrm{O} / \mathrm{H}_{2}^{16} \mathrm{O}$ being respectively about $3 \times 10^{-4}$ and $2 \times 10^{-3}$. The lower volatility of $\mathrm{HDO}$ and $\mathrm{H}_{2}^{18} \mathrm{O}$ compound to $\mathrm{H}_{2}^{16} \mathrm{O}$ is responsible for isotopic fractionation when processus of evaporation or condensation take place. Therefore we observe an isotopic fractionation at each successive step in the cycle of atmospheric water in nature, depending on the different conditions prevailing at the surface of the oceans and in the precipitating clouds.

Artificial tritium has been injected into the stratosphere by thermonuclear explosions. It is used as a third tracer in the study of the cycle of water, taking advantage of the fact that the place and data of its injection are known.

The study of the distribution of deuterium, oxygen 18 and tritium in natural waters leads to applications in meteorology, hydrology, glaciology and oceanography.

\section{Quelques références bibliographiques}

[1] Dansgaard, W., Stable isotopes in precipitation. Tellus 16 (1964) 436-468.

[2] Macklin, W. C., Merlivat, L. and Stevenson, C. M., The analysis of a hailstone. Q.J. R. Meteorol. Soc. 96 (1970) 472-486.

[3] Isotope hydrology, 1970, Proceedings of a symposium, Vienna, International Atomic Energy Agency, Vienna, 1970.

[4] Isotope techniques in ground water hydrology, 1974, Proceedings of a symposium, Vienna, International Atomic Energy Agency, Vienna, 1974.

[5] Dansgaard, W., Johnsen, S. J., Clausen, H. B. and GunDESTRUP, N., Stable isotope glaciology. Meddel. Groenl. 197 (1973) 2.
[6] Ḿerlivat, L., Ravoire, J. and Vergnaud, J. P., Tritium and deuterium content of the snow in Groenland. Earth Planet. Sci. Lett. 19 (1973) 235-240.

[7] CRAIG, H. and Gordon, L. I., Deuterium and oxygen 18 variations in the ocean and the marine atmosphere in conference on stable isotopes in Oceanographic Studies and Paleotemperatures (edited by V. Lishi e Giglii) pp. 9-130, 1965. Laboratorio di geologica nucleare, Pisa, Italy.

[8] Merlivat, L. and Coantic, M., 1975, Study of mass transfer at the air-water interface by an isotopic method. $J$. Geophys. Res. 80 (1975) 3455. 